\title{
Application of information technology of value-oriented management of art projects
}

\author{
D. Bas ${ }^{{ }^{*}}$, O. Bielova ${ }^{2 *}$ \\ ${ }^{1}$ Cherkasy State Technological University, Cherkasy, Ukraine \\ 2"KROK" University, Kyiv, Ukraine \\ *Corresponding author. E-mail: dimabass1990@gmail.com, belovaelenag@ gmail.com \\ Paper received 14.12.19; Accepted for publication 28.12.19.
}

https://doi.org/10.31174/SEND-NT2019-215VII26-11

\begin{abstract}
Absract. This study contains material on the application of value-oriented project management methodology in artistic activities. The analysis of scientific publications revealed that modern information technologies do not simultaneously take into account the value and risks associated with stakeholders of the art project. The practical implementation of information technology of value-oriented art project management is offered, which allows to maximize value and minimize the negative impact of risks that may arise during the implementation of art projects and have both positive and negative impact on them. It is established that the results of the practical implementation of information technology will give the leader and his team members an effective tool for ensuring the value of each stakeholder of the art project.
\end{abstract}

Keywords: value-oriented project management, art project, information technology, stakeholders, value, risks.

Introduction. Introduction of project approach in any sphere of human activity gives a new impulse to its development, this also applies to artistic activity. [1]. Implementation of any project has a specific mission and goals of the customer in accordance with his position, which leads to the creation of new value, characterized by uniqueness, distinguishing features and innovations [2].

Review of publications on the topic. In previous studies, the author analyzed the application of the project approach to artistic activity, definitions of the term "art project" are given, its peculiarities and uniqueness are revealed [3]. In addition, art project stakeholders have been identified [4].

The purpose of this study is to conduct practical application of information technology value-oriented art project management.is to assess the impact of personnel risks and conflicts in scientific projects using cognitive modeling.

Materials and methods. With a view to practical implementation of the author developed models and methods of value-oriented art project management, it is suggested to consider an example of an art project $[4,5]$. In the first stage, we will analyze the environment of the art project, including the identification of stakeholders, their values and the risks associated with them.

Identification of stakeholders of an art project is to define and describe stakeholders who have both a positive and a negative impact on the project implementation. $[4,5$, $6]$. The list of stakeholders of the art project is given in Table 1 .

Table 1. Description of art project's stakeholders

\begin{tabular}{|c|c|c|c|c|}
\hline № & Stakeholder (role) & Performer & $\begin{array}{l}\text { Value fac- } \\
\text { tors }\end{array}$ & Art project's risks \\
\hline 1 & 2 & 3 & 4 & 5 \\
\hline 1 & Art project manager & Tenga O.P. & $\mathrm{E}, \mathrm{S}, \mathrm{G}$ & $\begin{array}{l}\text { force majeure, human, communication, financial, } \\
\text { customer/consumer, valuable }\end{array}$ \\
\hline 2 & Art project team & Artists & $\mathrm{E}, \mathrm{K}, \mathrm{G}, \mathrm{Pr}$ & $\begin{array}{l}\text { creative, psychological, human, communication, } \\
\text { financial, customer/consumer, valuable }\end{array}$ \\
\hline 3 & \begin{tabular}{|l|} 
Initiator, customer, \\
owner, investor \\
\end{tabular} & Ministry of Culture of Ukraine & $\mathrm{S}, \mathrm{Pr}$ & $\begin{array}{l}\text { force majeure, communication, financial, custom- } \\
\text { er/consumer, valuable }\end{array}$ \\
\hline 4 & $\begin{array}{l}\text { Competitors of the } \\
\text { main project stake- } \\
\text { holders }\end{array}$ & Union of Artists of Ukraine & $\mathrm{S}, \mathrm{Pr}$ & creative, psychological, communication \\
\hline 5 & Authorities & $\begin{array}{l}\text { Cabinet of Ministers of Ukraine, } \\
\text { Verkhovna Rada of Ukraine, local author- } \\
\text { ities }\end{array}$ & $\mathrm{S}, \mathrm{P}, \mathrm{Vh}$ & social, force majeure, communication \\
\hline 6 & $\begin{array}{l}\text { Public groups and } \\
\text { organizations, popula- } \\
\text { tion }\end{array}$ & \begin{tabular}{|l|} 
Ministry of Information Policy of \\
Ukraine, National Art Museum of \\
Ukraine, population
\end{tabular} & $\mathrm{E}, \mathrm{S}, \mathrm{P}, \mathrm{Vh}$ & social, force majeure, communication \\
\hline 7 & Contractors/Suppliers & $\begin{array}{l}\text { Enterprises that provide material re- } \\
\text { sources for the implementation of the art } \\
\text { project will be determined by the results } \\
\text { of procurement procedures }\end{array}$ & E, S, P, Vh & $\begin{array}{l}\text { force majeure, technical/material, communication, } \\
\text { financial }\end{array}$ \\
\hline 8 & $\begin{array}{l}\text { Consumers of final } \\
\text { products }\end{array}$ & State, art critics, critics, population & $\begin{array}{l}\text { E, S, G, P, } \\
\text { Vh }\end{array}$ & $\begin{array}{l}\text { psychological, social, human, communication, cus- } \\
\text { tomer/consumer, valuable }\end{array}$ \\
\hline
\end{tabular}

Results and discussion. The second stage is to analyze stakeholders' impact on the project, taking into account their values and risks. To do this, we will rank the stakeholders of the art project by such criteria as: area of authority/responsibility; area of direct influence and area of indi- rect influence [5, 6]. The results of this ranking will be presented as Fig. 1. In the third stage, we will identify the interests of each stakeholder with their values and risks in relation to the project and its tools to influence the project. The results are presented in the form of Table $2[4,6]$. 
The fourth stage is to determine the degree of support and opposition to the stakeholders of the art project, taking into account their values and risks. [4, 6]. To do this, we will conduct a procedure for evaluating two parameters of stakeholder importance $(\mathrm{X} / \mathrm{Y})$ : the level of sup- port/opposition by stakeholder of the art project $(\mathrm{X})$ and the level of stakeholder influence on the art project (Y). The results of expert assessment of the levels of support/counteraction and impact will be given in the form of a classic stakeholder map and presented as a fig. 2.

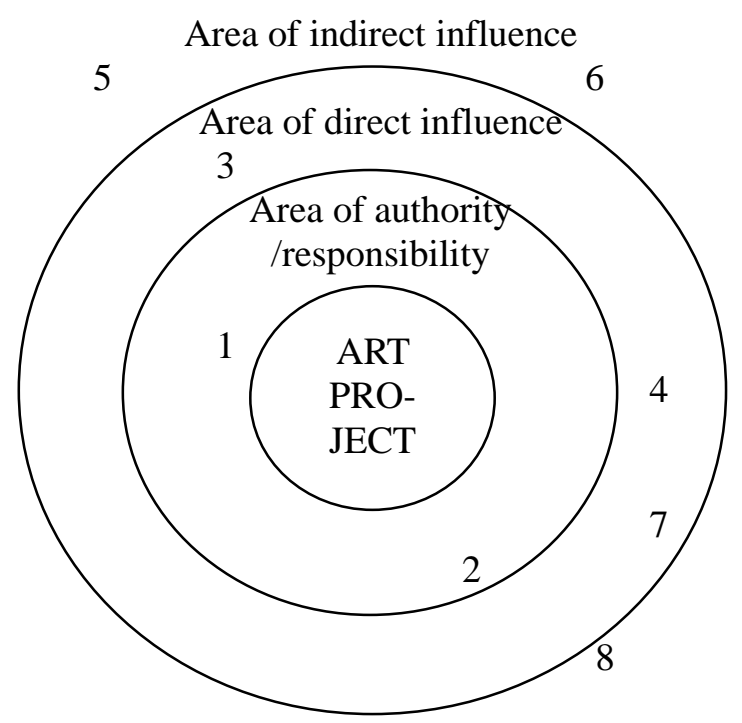

Fig. 1. Areas of stakeholders' influence on the art project

Table 2. Interests of art project's stakeholders

\begin{tabular}{|c|c|c|c|}
\hline \\
\hline № & Stakeholder (role) & Interests/motives & Impact tools \\
\hline 1 & 2 & 3 & 4 \\
\hline 1 & Art project manager & $\begin{array}{l}\text { Interested in successful and timely } \\
\text { implementation of the art project }\end{array}$ & Ensuring quality and timely execution of the art project \\
\hline 2 & Art project team & $\begin{array}{l}\text { Interested in successful and timely } \\
\text { implementation of the art project }\end{array}$ & Ensuring quality and timely execution of the art project \\
\hline 3 & $\begin{array}{l}\text { Initiator, customer, owner, } \\
\text { investor }\end{array}$ & $\begin{array}{l}\text { Interested in getting and enjoying an } \\
\text { art product }\end{array}$ & $\begin{array}{l}\text { Correct and clear wording of the idea of an art product, re- } \\
\text { quirements for it and setting a task for its creation, timely } \\
\text { allocation of funds }\end{array}$ \\
\hline 4 & $\begin{array}{l}\text { Competitors of the main } \\
\text { project stakeholders }\end{array}$ & $\begin{array}{l}\text { Interested in not receiving an art prod- } \\
\text { uct }\end{array}$ & Making a negative impact on the creation of an art product \\
\hline 5 & Authorities & $\begin{array}{l}\text { Interested in getting an art product and } \\
\text { replenishing the budget from its } \\
\text { presentation }\end{array}$ & Creation of appropriate conditions by the State \\
\hline 6 & $\begin{array}{l}\text { Public groups and organiza- } \\
\text { tions, population }\end{array}$ & Interested in presenting an art product & Timely exhibit of the art product for review \\
\hline 7 & Contractors/Suppliers & $\begin{array}{l}\text { Interested in supplying goods, works } \\
\text { and services and earning a profit }\end{array}$ & Timely delivery of goods, works and services \\
\hline 8 & Consumers of final products & $\begin{array}{l}\text { Interested in getting an art product, } \\
\text { reviewing it and enjoying it }\end{array}$ & Timely purchase of tickets for review \\
\hline
\end{tabular}

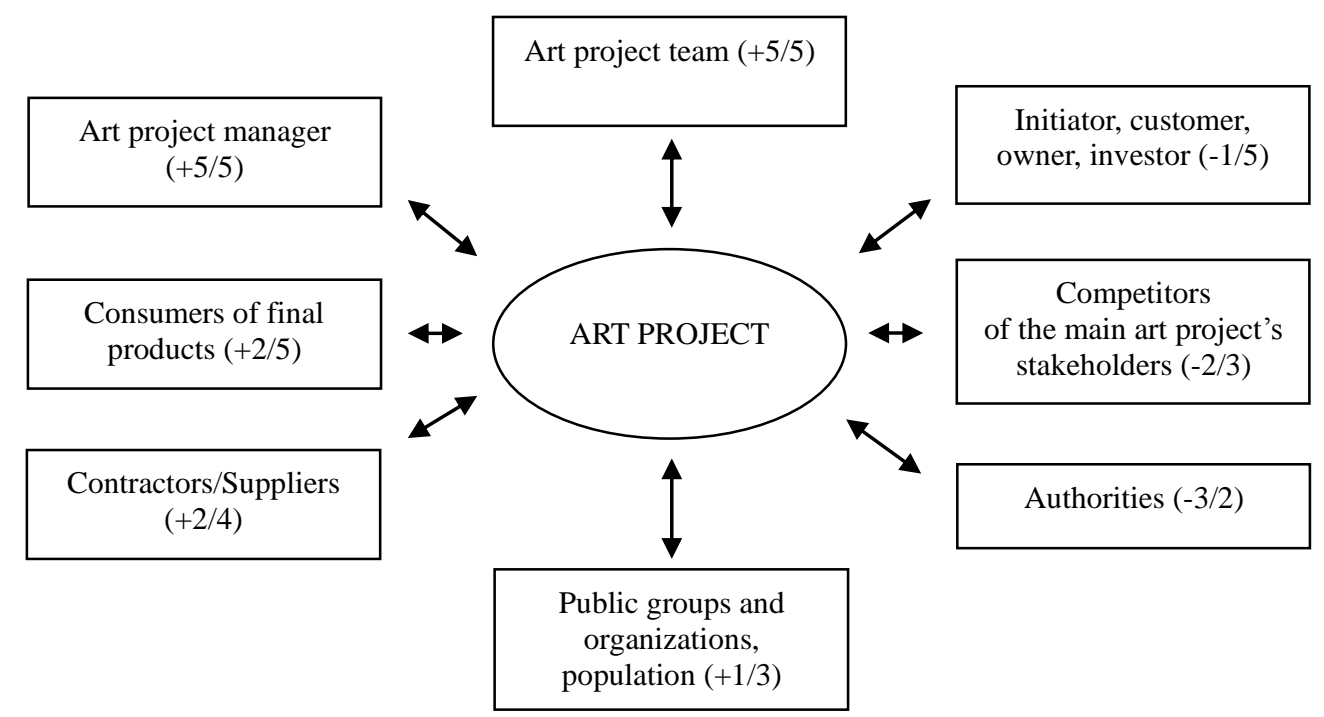

Fig. 2. A stakeholders' map of the art project with support/response and impact assessment 
The fifth stage identifies problematic situations in the project implementation process, taking into account stakeholder's values and risks [4, 6]. Results of this stage are given in the form of Table 3.

The sixth stage is psychological analysis of project's stakeholders, taking into account stakeholder's values and risks. At this stage, the project manager and his team need to have a psychological portrait of each stakeholder individually [7]. First of all, it is necessary to know that among the outward signs psychologically informative include: language; facial expressions, gestures, pose, pantomime, look; appearance; anatomical properties of the physical image.

Table 3. Identification of problematic situations of an art project related to the activity or inaction of stakeholders

\begin{tabular}{|c|l|l|}
\hline № & \multicolumn{1}{|c|}{ Stakeholder (role) } & \multicolumn{1}{|c|}{ Problem situations of an art project } \\
\hline 1 & \multicolumn{1}{|c|}{2} & \multicolumn{1}{c|}{3} \\
\hline 1 & Art project manager & $\begin{array}{l}\text { Insufficient experience in performing art projects, inability to communicate with other } \\
\text { stakeholders, inability to provide a sufficient psychological climate in the team of the art } \\
\text { project }\end{array}$ \\
\hline 2 & Art project team & $\begin{array}{l}\text { Insufficient stress resistance, lack of communication skills, inability to comply with the } \\
\text { requirements of an art product }\end{array}$ \\
\hline 3 & $\begin{array}{l}\text { Initiator, customer, owner, inves- } \\
\text { tor }\end{array}$ & Inability to articulate the idea and requirements for an art product, lack of funds \\
\hline 4 & $\begin{array}{l}\text { Competitors of the main project } \\
\text { stakeholders }\end{array}$ & $\begin{array}{l}\text { Lack of interest in the art product, creating obstacles in the process of art project's imple- } \\
\text { mentation }\end{array}$ \\
\hline 5 & Authorities & $\begin{array}{l}\text { Lack of political will to make necessary decisions regarding the art product, unwillingness } \\
\text { to promote the art product's introduction }\end{array}$ \\
\hline 6 & $\begin{array}{l}\text { Public groups and organizations, } \\
\text { population }\end{array}$ & Lack of quality content to promote an art project and an art product \\
\hline 7 & Contractors/Suppliers & Poor quality, untimely delivery of goods, works, services \\
\hline 8 & Consumers of final products & Dissatisfaction with the art product, low demand for the art product \\
\hline
\end{tabular}

The seventh stage develops stakeholder's engagement strategies, taking into account stakeholder's values and risks.

To ensure the value management of the art project $[4,5]$, based on the data in Table 1, we will poll each stakeholder on its value in the future art product and present its results in the form of a Table 4.

Table 4 shows how valuable each project stakeholder is in quantitative terms.

The next step is to assess stakeholder's risks, we propose their practical application in terms of risk assessment that may arise from the activity or inaction of stakeholders of the art project. For this purpose, the project manager assesses the likelihood of risks for each stakeholder and their possible impact on the art project, the results of which are presented in Table 5.
Table 4. Values analysis for each stakeholder of art project

\begin{tabular}{|l|c|c|c|c|c|c|c|c|}
\hline \multirow{2}{*}{ Stakeholders } & \multicolumn{7}{|c|}{ Art Finctions } \\
\cline { 2 - 7 } & $\mathrm{E}$ & $\mathrm{S}$ & $\mathrm{K}$ & $\mathrm{G}$ & $\mathrm{P}$ & $\mathrm{Pr}$ & $\mathrm{Vh}$ & \\
\hline Art project manager & 1,4 & 1,5 & 2,0 & 0,6 & 1,2 & 0,7 & 1,2 & 8,6 \\
\hline Art project team & 0,5 & 3,5 & 0,9 & 0,2 & 1,6 & 4,8 & 1,2 & 12,7 \\
\hline $\begin{array}{l}\text { Initiator, customer, owner, } \\
\text { investor }\end{array}$ & 5,6 & 0,2 & 0,9 & 4,2 & 2,5 & 0,2 & 1,6 & 15,2 \\
\hline $\begin{array}{l}\text { Competitors of the main } \\
\text { project stakeholders }\end{array}$ & 0,1 & 0,4 & 3,0 & 1,5 & 6,3 & 4,2 & 1,2 & 16,7 \\
\hline Authorities & 3,5 & 6,3 & 0,6 & 0,8 & 1,2 & 0,1 & 4,8 & 17,3 \\
\hline $\begin{array}{l}\text { Public groups and organi- } \\
\text { zations, population }\end{array}$ & 6,3 & 4,8 & 1,5 & 2,4 & 0,2 & 0,6 & 3,0 & 18,8 \\
\hline Contractors/Suppliers & 0,8 & 2,4 & 6,3 & 3,5 & 4,8 & 1,2 & 0,2 & 19,2 \\
\hline $\begin{array}{l}\text { Consumers of final prod- } \\
\text { ucts }\end{array}$ & 5,6 & 5,4 & 1,2 & 2,0 & 0,1 & 0,4 & 3,5 & 18,2 \\
\hline
\end{tabular}

Table 5. Risk analysis of each art project's stakeholder

\begin{tabular}{|c|c|c|c|c|c|c|c|c|c|c|c|}
\hline \multirow[b]{2}{*}{ Stakeholders } & \multicolumn{10}{|c|}{ Risks } & \multirow[t]{2}{*}{$\mathrm{Ri}$} \\
\hline & 葾 & 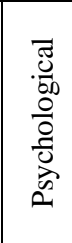 & 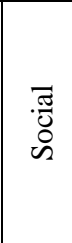 & 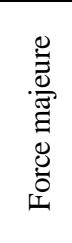 & 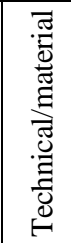 & $\begin{array}{c}\stackrel{\Xi}{\Xi} \\
\text { 壱 }\end{array}$ & 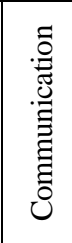 & 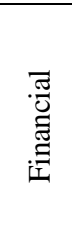 & 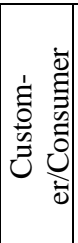 & $\begin{array}{l}\frac{0}{0} \\
\frac{\pi}{3} \\
\stackrel{0}{>}\end{array}$ & \\
\hline 1 & 2 & 3 & 4 & 5 & 6 & 7 & 8 & 9 & 10 & 11 & 12 \\
\hline Art project manager & 0,08 & 0,48 & 0,20 & 0,02 & 0,12 & 0,35 & 0,35 & 0,12 & 0,06 & 0,20 & 1,98 \\
\hline Art project team & 0,02 & 0,42 & 0,09 & 0,06 & 0,04 & 0,48 & 0,48 & 0,20 & 0,06 & 0,12 & 1,97 \\
\hline $\begin{array}{l}\text { Initiator, customer, owner, } \\
\text { investor }\end{array}$ & 0,02 & 0,72 & 0,09 & 0,02 & 0,20 & 0,24 & 0,30 & 0,63 & 0,35 & 0,63 & 3,20 \\
\hline $\begin{array}{l}\text { Competitors of the main } \\
\text { project stakeholders }\end{array}$ & 0,01 & 0,15 & 0,30 & 0,06 & 0,20 & 0,08 & 0,06 & 0,10 & 0,03 & 0,06 & 1,05 \\
\hline Authorities & 0,20 & 0,30 & 0,06 & 0,04 & 0,02 & 0,08 & 0,20 & 0,28 & 0,02 & 0,09 & 1,29 \\
\hline $\begin{array}{l}\text { Public groups and organi- } \\
\text { zations, population }\end{array}$ & 0,06 & 0,12 & 0,15 & 0,03 & 0,02 & 0,06 & 0,06 & 0,10 & 0,02 & 0,08 & 0,70 \\
\hline Contractors/Suppliers & 0,02 & 0,16 & 0,63 & 0,15 & 0,72 & 0,30 & 0,42 & 0,30 & 0,30 & 0,20 & 3,20 \\
\hline $\begin{array}{l}\text { Consumers of final prod- } \\
\text { ucts }\end{array}$ & 0,72 & 0,56 & 0,12 & 0,02 & 0,02 & 0,06 & 0,15 & 0,02 & 0,06 & 0,72 & 2,45 \\
\hline
\end{tabular}


Table 6. Determination of integrated value index of the i-th stakeholder

\begin{tabular}{|l|c|c|c|}
\hline \multicolumn{1}{|c|}{ Stakeholders } & $\mathrm{V}_{\mathrm{i}}$ & $\mathrm{R}_{\mathrm{i}}$ & $\mathrm{VV}_{\mathrm{i}}$ \\
\hline Art project manager & 8,60 & 1,98 & 6,62 \\
\hline Art project team & 12,70 & 1,97 & 10,73 \\
\hline $\begin{array}{l}\text { Initiator, customer, owner, inves- } \\
\text { tor }\end{array}$ & 15,20 & 3,20 & 12,00 \\
\hline $\begin{array}{l}\text { Competitors of the main project } \\
\text { stakeholders }\end{array}$ & 16,70 & 1,05 & 15,65 \\
\hline Authorities & 17,30 & 1,29 & 16,01 \\
\hline $\begin{array}{l}\text { Public groups and organizations, } \\
\text { population }\end{array}$ & 18,80 & 0,70 & 18,10 \\
\hline Contractors/Suppliers & 19,20 & 3,20 & 16,00 \\
\hline Consumers of final products & 18,20 & 2,45 & 15,75 \\
\hline
\end{tabular}

Table 5 shows what risks each stakeholder of an art project has in quantitative terms. Thus, assessing the risks associated with the activity or inactivity of an art project stakeholder gives information to the project manager not only about the risks that the project management requires, but also the consequences of their impact, which should be considered when developing comprehensive risk management measures for an art project.

The information technology of value-oriented art project management is to calculate an integrated value indicator of the i-th stakeholder $\left(\mathrm{VV}_{\mathrm{i}}\right)$, which is based on the value and risk calculations of each stakeholder. According to the data obtained in Tables 4 and 5, it is possible to calculate an integrated value index of each stakeholder of an art project, the results of which are presented in the form of Table 6 .

Table 6 shows that all stakeholders of the art project, except the art project manager and his team, have a high level of integrated value, that is $\mathrm{VV}_{\mathrm{i}}>12$, and, therefore, do not require additional measures to develop strategies to increase this level. Art project manager and his team received an average level of the Integrated Value Index, that is $6<$ $\mathrm{VV}_{\mathrm{i}}<12$, therefore, strategies need to be developed to increase this level. In this case, strategies for increasing the level of the integrated value indicator include: financial incentives, organization of advanced training in psychology, business communication skills, cultural and aesthetic development.

Conclusions. From the above it is clear that information technology of value-oriented art project management provides an effective program product for quality and timely planning of the art project, as well as providing control and monitoring of its implementation.

\section{REFERENCES}

1. A Guide to the Project Management Body of Knowledge (PMBOK ${ }^{\circledR}$ Guide) - Six Edition. - USA. - PMI, 2017. - 574 p.

2. A guide to managing innovative projects and programs. P2M. Vol. 1, Version 1.2:English translation/ed. prof. S.D. Busheva. K.:Science. world, 2009. - 173pp.

3. Bas D. V. Art projects, their features and definitions/D. V. Bas // Bulletin of Cherkasy State Technological University. Series: Technical Sciences. - № 3, 2016. - PP. 57-62.

4. Danchenko O.В. Ідентифікація стейкхолдерів артпроектів/O.B.Danchenko, D.V. Bas // Topical issues of modern science and practice. Materials of scientific and practical conference (November 15, 2018, Kyiv). - Kyiv: "KROK" University, 2018. - pp. 387-389.
5. Bas D. V. Methods of value-oriented art project management/D. V. Bas // Bulletin of Cherkasy State Technological University. Series: Technical Sciences. - Cherkasy, 2019. - № 2. PP. 107-116.

6. Finogeeva A.I. Improvement of the mechanism of company's interaction with stakeholders/A.I. Finogeeva // MES. - 2017. №3 (97). - Access mode: https://cyberleninka.ru/article/n/sovershenstvovaniemehanizma-vzaimodeystviya-kompanii-s-zainteresovannymistoronami (date of circulation: 05.06.2018).

7. Kopets L.V. Psychology of personality. Educ. tool. for students. universities. K.: View. home. "Kyiv-Mohyla Academy", 2008. $-458 \mathrm{pp}$. 